Purpose, Meaning, And Action 



\title{
Purpose, Meaning, and ACTION
}

Control Systems Theories

in Sociology

\author{
Edited by \\ Kent A. McClelland \\ and
}

Thomas J. Fararo 


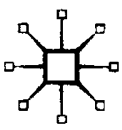

PURPOSE, MEANING, AND ACTION

(C) Kent A. McClelland and Thomas J. Fararo, 2006.

Softcover reprint of the hardcover 1st edition 2006 978-1-4039-6798-5

All rights reserved. No part of this book may be used or reproduced in any manner whatsoever without written permission except in the case of brief quotations embodied in critical articles or reviews.

First published in 2006 by

PALGRAVE MACMILLAN'M

175 Fifth Avenue, New York, N.Y. 10010 and

Houndmills, Basingstoke, Hampshire, England RG21 6XS

Companies and representatives throughout the world.

PALGRAVE MACMILLAN is the global academic imprint of the Palgrave Macmillan division of St. Martin's Press, LLC and of Palgrave Macmillan Ltd. Macmillan ${ }^{\circledR}$ is a registered trademark in the United States, United Kingdom and other countries. Palgrave is a registered trademark in the European Union and other countries.

ISBN 978-1-349-73419-1 ISBN 978-1-137-10809-8 (eBook)

DOI 10.1007/978-1-137-10809-8

Library of Congress Cataloging-in-Publication Data is available from the Library of Congress.

A catalogue record for this book is available from the British Library.

Design by Newgen Imaging Systems (P) Ltd., Chennai, India.

First edition: June 2006

10987654321

Transferred to digital printing in 2007. 


\section{CONTENTS}

List of Figures vii

List of Tables ix

Preface xi

1. Introduction: Control Systems Thinking in Sociological Theory 1

Thomas J. Fararo and Kent A. McClelland

\section{Part 1 From Perceptual Control to Institutional Control}

2. Understanding Collective Control Processes Kent A. McClelland

3. Purposive Collective Action

Clark McPhail, David S. Schweingruber, and Alin Ceobanu

4. The Why, What, and How of Selling Door-to-Door:

Levels of Purpose and Perception in a

Sales Company

David S. Schweingruber

5. Institutionalized Social Action: Control at the

Program Level

Thomas J. Fararo and John Skvoretz

\section{Part 2 Affect Control and Identity Control in Social Interaction}

Overview and Comparison of Two Theories

6. Introduction to Affect Control Theory 
7. Control Theories of Identity, Action, and Emotion:

In Search of Testable Differences between Affect

Control Theory and Identity Control Theory

Lynn Smith-Lovin and Dawn T. Robinson

\section{Studies in Affect Control}

8. Sentiment Formation in Social Interaction

David R. Heise

9. Guilty Americans and Shameful Japanese? An Affect Control Test of Benedict's Thesis

Herman W. Smith and Yap MiowLin

10. The Affect Control Theory of Emotions: The Case of Depression

Neil J. MacKinnon and Michelle M. Goulbourne

\section{Studies in Identity Control}

11. Perceptions of Leadership in Groups: An Empirical Test of Identity Control Theory Peter J. Burke

12. The Moral Identity: A Principle Level Identity

Appendix 1-The Closed-Loop, Negative Feedback

Model: Some Quantitative Evidence

Clark McPhail and David Schweingruber

Contributors

Index of Names

Index of Subjects 


\section{LIST OF FIGURES}

1.1 A Negative Feedback System for Controlling Perception

1.2 Interconnections in a Hierarchical Control System 13

2.1 Simulation of a Single Control System in Action 34

2.2 A Generic Model of a Collective Control Process 36

2.3 Simulation of Two Control System Working Together 37

2.4 Simulation of Two Control System Working in Conflict

3.1 Complex EFCA Permutations Rally Period 66

3.2 A Three Level Hierarchy of Perception Control Systems

6.1 Evaluation Scale, Fundamental Sentiments for "a baby"

6.2 A Control Model Modified to Show Affect Control Theory Factors

7.1 Identity Control Theory's View of the Identity Process.

8.1 Changing Behavior Evaluations in the Eygpt-Israel Dyad

8.2 Correlations Between Predicted Versus Observed Behavior

9.1 EPA Profiles for Feeling Guilty among American and Japanese Men and Women

9.2 EPA Profiles for Feeling Ashamed among American and Japanese Men and Women

9.3 Simulated Emotional Norm Boundaries for American Familial Roles

9.4 Simulated Emotional Norm Boundaries for American Familial Roles

11.2 Structural Diagram for Analytic Models One and Two 
11.3 Structural Diagram for Analytic Model Three 279

12.1 Hierarchy of Identity Control Process 299

12.2 Emotional Reaction by Return Money and Moral Identity

12.3 Emotional Reaction by Return Wallet and Moral Identity

12.4 Emotional Reaction by Charity Donation and Moral Identity

12.5 Emotional Reaction by Homeless Donation and Moral Identity

A.1 Traces of an Individual Pursuit Tracking Task 


\section{LIST OF TABLES}

3.1 Estimated Proportion Participating in an EFCA 61

3.2 EFCA Means by Period of Time 63

4.1 Levels of Purpose and Perception 94

4.2 Some Enterprise Company Emotional Purposes (Why Purposes) 99

5.1 Rolegrams for Server and Customer $\quad 120$

6.1 Fundamental Sentiments-Epa Profiles 142

6.2 Comparison of Transient Impressions with Fundamental Sentiments for the Event, "Manager Collaborates with Employee"

6.3 Comparison of Transient Impressions with Fundamental Sentiments for the Event, "Manager Criticizes Employee"

6.4 EPA Profiles for Fundamental Sentiments from Four Cultures $\quad 155$

8.1 Illustrative Events from the COPDAP Data Set 195

8.2 Partitioning of Explained Variance in Evaluation, Potency, and Activity of Observed Behaviors 203

9.1 Summary of Benedict's Typology of Guilt and Shame-Based Societies

10.1 Characteristic Emotions for Identity Prototypes 250

10.2 Structural Emotions of Object-Person Ranked According to Closeness to Depression 254

10.3 Structural Emotions of Object-Person Ranked According to Closeness to Depression 258

11.1 Items, Factor Loadings, and Reliability for Task Leadership Identity and Task Leadership Performance

11.2 Means, Standard Deviations, and Correlations among Variables.

11.3 Structural Coefficients for the Analysis of Model 1 
11.4 Structural Coefficients for the Analysis of Model 2

11.5 Structural Coefficients for the Analysis of Model 3

12.1 Principle Components Factor Analysis for Moral Identity 303

12.2 Means and Standard Deviations of Variables 305

12.3 Correlations among Variables 306

12.4 Logistic Regressions for Moral Situations 306

12.5 Ordinary Least Squares Regression of Emotional Reactions Following Moral Situations

12.6 Ordinary Least Squares Regression of Emotional Reactions Following Moral Situations

A.1 Quantitative Evidence for the Closed-Loop, Negative Feedback Control System 


\section{PREFACE}

$\mathrm{T}$ he chapters of this book combine theoretical ideas with empirical studies and also with simulation tools to show one important way that cybernetic conceptualizations of control, which first appeared on the scene more than half a century ago when Norbert Wiener coined the term cybernetics and highlighted the importance of negative feedback, continue to have relevance to contemporary sociology. The book brings together for the first time examples of the work of each of a number of independent research groups that have contributed to a recent "cybernetic turn" in sociology, with contributions from leading members of each group, and an emphasis throughout on the common theoretical orientation underlying their research.

Although the focus of this volume is on research-oriented theorizing that employs the idea of a control system, we make no pretence of offering a comprehensive review of all the ways in which cybernetic ideas influence contemporary sociology. In particular, as we note in chapter 1 , a where we discuss the intellectual setting for this volume, the ideas of Niklas Luhmann are not within its scope. In addition, the research programs represented in this book should not be confused with the "control theory" approach in criminology and, more generally, in the study of deviance. The idea of control, as used in this volume, is associated with a general model of human behavior grounded in cybernetics. According to this model, all human action involves control as a relation among purpose, perception (or meaning), and overt behavior. When two or more actors interact, their interactions imply a "coupling" of efforts to realize goals that may or may not be compatible, giving rise to the varied phenomena studied by sociologists. Our contributors, in one way or another, explicate the meaning of this idea and report research embodying it.

Thus, the chapters of this volume combine the symbolic interactionist idea that human society emerges by means of the symbols that permeate social interactions and institutions with the principle that human behavior can be understood in terms of a fundamental control mechanism. We believe that these linked ideas belong in the core of 
sociological theory and can aid sociologists and other social scientists in developing more powerful explanations of the social world. The reader is asked to view the contributions here in that light, that is, as both modest achievements and as promising indicators of a new direction in sociological thinking.

Although the contributors to this book have never met together in a single location, the book to a great extent represents a group effort. McClelland initiated the project by contacting Burke, Fararo, Heise, and McPhail, all of whom enthusiastically enlisted their associates and coworkers to contribute to the book. Fararo graciously volunteered to serve as coeditor. An internal review process was set up, by which each of the chapters was reviewed by at least one other contributor in addition to the editors, and we are extremely grateful for how promptly and cheerfully the contributors complied with a rigorous schedule for drafting, reviewing, and revising chapters.

We are grateful, also, to Farideh Koohi-Kamali of Palgrave Macmillan for her willingness to take on this project, as well as Elizabeth Sabo, Gabriella Pearce and Julia Cohen of Palgrave Macmillan and Maran Elancheran of Newgen Imaging Systems for their care and efficiency in bringing the book through the publication process. We thank Stacy Kossoy for her valuable contributions to the initial editing process and Karen Groves, Stephanie Puls, and especially Linda Price in the Carnegie Academic Support Office of Grinnell College for their indispensable assistance in every phase of the project. Finally, we are grateful for the loving support and encouragement provided by our families, and especially Katherine McClelland and Irene Fararo.

Kent A. McClelland

Thomas J. Fararo

December 13, 2005 